\title{
This midlife startup owner has pivoted twice
}

\author{
Chris Farrell
}

KEYWORDS: Startups, crisis management, pivot.

\begin{abstract}
Julie Steller got creative - and fast - once the pandemic hit / Credit: courtesy of Julie Steller
\end{abstract}

EDITOR'S NOTE: This article is part of America's Entrepreneurs(https://www.nextavenue.org/americasentrepreneurs/) , a Next Avenue initiative made possible by the Richard M. Schulze Foundation (https://www.schulzefamilyfoundation.org/) and EIX. (https://eiexchange.com/)

Julie Steller, the 63-year-old founder of Steller Handcrafted Goods in Minneapolis, is getting used to making pivots.

Steller first turned her passion for craft making into a small business in 2012. It was all about using upcycled wool sweaters, authentic Nordic braid and other quality materials to make mittens, shawls, hats, socks and similar products with Scandinavian flair and practical sensibility.

Experience had taught her to anticipate that sales would grow about $10 \%$ in 2020 . That is, until COVID-19 hit.

\section{Her First COVID-19 Business Pivot}

Like so many small businesses and microenterprises, sales for Steller dried up last year, with stores and craft fairs abruptly shuttered. Before the pandemic, she typically did very little business on her website. So Steller laid off her 14 employees in March 2020.

"People aren't born to create a business plan," says WomenVenture's Moore. "You can learn." products," she recalled thinking. "It was really depressing."

But Steller quickly realized that there was a market for COVID-19 masks(https://www.nextavenue.org/sewingmachine-covid-19/). So, she switched her mitten business to one dedicated to mask-making.

Sales were brisk and she ended up with 18 people sewing the masks, including everyone she'd laid off. Steller mostly sold the masks online and from a selfserve store she set up on her front porch in her Minneapolis neighborhood.

"We worked very hard all year long," she says.

And now it's time for another Steller pivot.

The economy is opening with the rollout of COVID-19 vaccines and mask demand has fallen, so the company is only producing two niche masks: $\mathrm{X}$-large and Scandinavian design.

Her current roster of 13 workers is mostly creating a broad range of one-of-a-kind repurposed products. Steller also overhauled her website for easier online shopping and sales.

Still, the past year was so unusual she says she doesn't have much of a feel for how strong demand will be in the post-pandemic economy.

\section{Her Second COVID-19 Business Pivot}

"We are like farmers," Steller says. "We have to plant the seed and pray for rain," she says.
Steller is something of an unlikely small business owner
These were gifted seamstresses who worked for her on contract, many to supplement their income.

"I can't keep spending money if there's nowhere to sell 
in the second half of life (https://www.nextavenue.org/americas-entrepreneurs/) in several respects (as you'll see in a moment). But other parts of her story are typical among encore entrepreneurs.

Most importantly, her experience illustrates a major theme of the second-life small business owner: The critical role community plays in the creation and the running of a startup.

Steller's is wide ranging. It includes an organization focused on helping women succeed at starting a business (Minneapolis' WomenVenture (https://www.womenventure.org/about.html) ); her employees; the local stores that sell her products and the event sponsors that let her showcase the repurposed crafts.

Community connections don't guarantee success for newbie second-act entrepreneurs, but they dramatically hike the odds of turning an idea or a passion into a real business.

"You have people you can reach out to," says Carrie Moore, chief advancement officer at WomenVenture, an organization that supports women-owned businesses through education, mentors, networking and a microlending program for low-income entrepreneurs.

\section{How She Became an Entrepreneur}

Briefly, here's the backstory to Steller Handcrafted Goods.

Steller has lived in the Elliott Park neighborhood of downtown Minneapolis since 1986 with her husband,
Tom Steller, a long-time pastor with Bethlehem Baptist Church. A stay-at-home mom, she raised six children.

She always enjoyed craft making and in the early 2000s, started creating items from repurposed Scandinavian sweaters - mostly for friends, but some sold at local craft fairs.

"I don't have any plans to retire. My husband doesn't either," she says. "We love our work so much."

Steller figured that at some point she'd get a job at Trader Joe's or someplace like it when she and Tom became empty nesters.

"I knew that I wanted to be home during the years we were raising kids," she says. "I also knew I had to work when they left."

Starting a business? Not on her radar screen.

But in 2012, Steller was invited to participate in the Norsk Høstfest in Minot, N.D, the largest Scandinavian festival in North America. At 53, the invitation spurred her to think through whether her craft was a hobby or a business.

So, she decided to give entrepreneurship a try.

\section{Getting Help Learning Business Basics}

Knowing nothing about launching or running a small business, she went to WomenVenture in 2012 to learn the basics.

"People aren't born to create a business plan," says WomenVenture's Moore. "You can learn."

Of course, starting and owning a business isn't easy. Steller had a steep learning curve. She borrowed money to fund an ambitious craft project early on and several unanticipated setbacks nearly sunk her business. But she persevered. 
Stories like Steller's reflect an underlying trend that is still underappreciated in the power centers of finance and politics. Mention entrepreneurship and the conversation will typically dwell on Silicon Valley-type ambitions. People will toss around terms like "scalability" and "disruption," as well as terms like venture capital and angel investors.

Yet what I've learned, after so many interviews in recent years with people like Steller, is how shared entrepreneurial verve really is across America.

No, venture capitalists will never look at these types of small businesses and microenterprises. But these companies provide growing numbers of people in the second half of life an income to help pay the bills while offering them - and their employees - opportunities for creativity.

\section{Changing the Idea of Entrepreneurship}

The ability of entrepreneurs like Steller to adjust to different economic and financial circumstances is, well, stellar. And there's a vibrant community of knowledge, advice and support for them to tap throughout the country (although many places could do much more to welcome encore entrepreneurs).

With the pandemic fading in the United States (fingers crossed), the economy revving up and the need for many people $50+$ to work, there's a good chance that the ranks of older entrepreneurs will expand. In 2020, the rate of new entrepreneurs was highest among the 45- to 54-year-old age group, according to the Kauffman Foundation. The second highest? The 54-to 64-year-old cohort.

A number of these new businesses will fail, undoubtedly. And some may grow into much larger enterprises, with lots of employees on payroll. Odds are, however, that many of them will make a go of it - at least if the new small business owner taps into available resources.

In that case, they may well echo Steller's outlook. "I don't have any plans to retire. My husband doesn't either," she says. "We love our work so much."
Multiply that sentiment and the result looks good for older households, society and the economy. 